\title{
Synthesis of tetrazole analogues of amino acids using Fmoc chemistry: isolation of amino free tetrazoles and their incorporation into peptides
}

\author{
Vommina V. Sureshbabu, ${ }^{*}$ Rao Venkataramanarao, Shankar A. Naik \\ and G. Chennakrishnareddy \\ Department of Studies in Chemistry, Central College Campus, Bangalore University, Dr. B. R. Ambedkar Veedhi, \\ Bangalore 560 001, India
}

Received 18 May 2007; revised 5 July 2007; accepted 20 July 2007

Available online 27 July 2007

\begin{abstract}
An efficient synthesis of tetrazole analogues of amino acids starting from $N^{\alpha}$-Fmoc amino acid in a three-step protocol is reported. The free amino tetrazoles were obtained in good yields and with excellent purity after removal of the Fmoc group. The synthesis of analogues of aspartic and glutamic acids in which the 5-tetrazolyl moiety is inserted at the $\beta / \gamma$ carboxyl group starting from Fmoc-Asn and Fmoc-Gln and the incorporation of these tetrazoles into peptides are also described.
\end{abstract}

(C) 2007 Elsevier Ltd. All rights reserved.

Tetrazoles, being an interesting class of heterocycles, find a wide range of applications as drugs in pharmaceuticals, ${ }^{1}$ cis-peptide bond mimics ${ }^{2}$ and bioisosteres ${ }^{3}$ for carboxylic acids. They are important precursors in medicinal chemistry owing to their increased resistance towards metabolic degradation pathways and have found increasing applications as catalysts ${ }^{4}$ in asymmetric synthesis. Tetrazoles have also been utilized in organometallic chemistry as effective stabilizers of metallopeptide structures and as peptide chelating agents. $^{5}$

The selective modification of amino acid chains in peptides and proteins is important in many areas of chemistry such as organic synthesis, the irreversible inhibition of enzymes and in the improvement of pharmacokinetic properties of peptide based drugs. Since, the acidity of the tetrazole group corresponds closely with that of a carboxylic acid, replacement of the C-terminal amino acid residue in biologically active peptides with a tetrazole analogue would create an interesting class of compounds for structure function relationship studies.

Keywords: Fmoc amino acids; Tetrazoles; Unnatural amino acids; $[2+3]$ Cycloaddition.

* Corresponding author. Tel.: +91 80 22961339; e-mail: hariccb@ rediffmail.com
Indeed, isosteric displacement of the C-terminus carboxylic acid with a tetrazole often preserves or improves the biological activity of the parent peptides and their mimetics.

Conventionally, 5 -substituted tetrazoles are synthesized ${ }^{6}$ by $[2+3]$ cycloaddition of an azide and a nitrile. However, disadvantages of these synthetic routes involve the use of expensive and toxic metals, strong Lewis acids and the in situ generation of hydrazoic acid which is highly toxic and explosive in nature. An alternative route to overcome some of these shortcomings was necessary. Sharpless et al., ${ }^{7}$ reported an efficient protocol for the synthesis of tetrazoles using sodium azide and zinc bromide in water/2-propanol mixture at reflux employing Z-protected amino acids as key synthons. Alternatively, tetrazole analogues of amino acids have been reported by Grzonka et al., ${ }^{8}$ from Z-protected amino nitriles using sodium azide and aluminium chloride in tetrahydrofuran at reflux. In continuation of our interest in incorporating a tetrazole heterocyclic moiety into amino acids and thereby peptides, we describe here our efforts to isolate amino free tetrazoles of $\alpha$-amino acids employing an Fmoc-protection strategy and their incorporation into peptides. Ley ${ }^{9}$ recently reported the utility of free amine proline tetrazole as a catalyst in asymmetric synthesis. This catalyst was prepared after deprotection of the Z-group from Z-proline tetrazole 
using a specifically designed $\mathrm{H}$-cube continuous flow hydrogenator. ${ }^{10}$ Although this process has led to complete removal of the Z-group in $4 \mathrm{~h}$, the expensive nature of palladium, the special apparatus and the difficulties encountered in isolating the product are some of the limitations in scaling-up this protocol. In addition, our efforts to obtain amino free tetrazoles from Boc-Phe tetrazole using TFA were unsuccessful. In this context, the use of a Fmoc protection strategy was of particular interest since the Fmoc group can be easily removed under mild basic conditions in solution and also permits the use of Trt and ${ }^{t}$ butyl groups for side chain protection, which can also be cleaved under mild conditions. ${ }^{11}$ We have envisaged a simple, four-step protocol for the synthesis of amino free tetrazole analogues of amino acids employing Fmoc chemistry in solution phase.

Pozdnev et al. ${ }^{12}$ reported the synthesis of Boc/Z-amino acid amides including Fmoc-Phe and Leu using the ditert-butyl pyrocarbonate $\left[(\mathrm{Boc})_{2} \mathrm{O}\right]$-pyridine system. A similar protocol with required modifications was employed for our synthesis of Fmoc-protected amino acid carboxamides (Scheme 1). Subsequent dehydration of the amides to the corresponding nitriles was achieved in excellent yields employing trifluoroacetic anhydride. ${ }^{13}$ This reagent was best suited for our protocol since DCC mediated dehydration requires the use of pyridine as a solvent, a strategy that does not fully support Fmocchemistry. Another dehydrating reagent, cyanuric chloride was not used because the synthetic protocol was aimed at keeping the $\alpha$-carboxyl group free in the case of side chain-derived tetrazole analogues. A characteristic peak around $2240 \mathrm{~cm}^{-1}$ in the IR spectrum confirmed the presence of a nitrile group. All the Fmoc- $\alpha-$ amino nitriles prepared were obtained as crystalline solids. The methodology introduced by Sharpless et al., ${ }^{7}$ for the conversion of $\alpha$-amino nitriles to 5-substituted tetrazoles $^{14}$ was found to be applicable in the case of the Fmoc-amino nitriles described herein. The reaction proceeds by addition of sodium azide and a catalytic amount of zinc bromide to $\alpha$-amino nitriles in water/2propanol (2:1) mixture at reflux for $16 \mathrm{~h}$. A simple work-up involving acidification and extraction yielded the corresponding tetrazoles as pure solids in yields around $80-90 \%$.

The Fmoc-group was deprotected using diethylamine in $\mathrm{CH}_{2} \mathrm{Cl}_{2}$ in $30 \mathrm{~min}$ to yield $\alpha$-amino tetrazoles. ${ }^{15}$ After evaporation of the solvent and trituration with ether, the compounds were isolated as pure solids (Table 1). The reaction sequence was found to be free from racemization $^{16}$ as determined by chiral HPLC of the methylated derivatives of the corresponding tetrazoles.

Further, the utility of Fmoc chemistry for inserting the tetrazole unit into the $\beta / \gamma$ carboxylic position of aspartic and glutamic acids was demonstrated (Scheme 2). It was envisaged that the carboxamido group present in the side chains of asparagine and glutamine could be readily exploited for the incorporation of a tetrazole moiety in

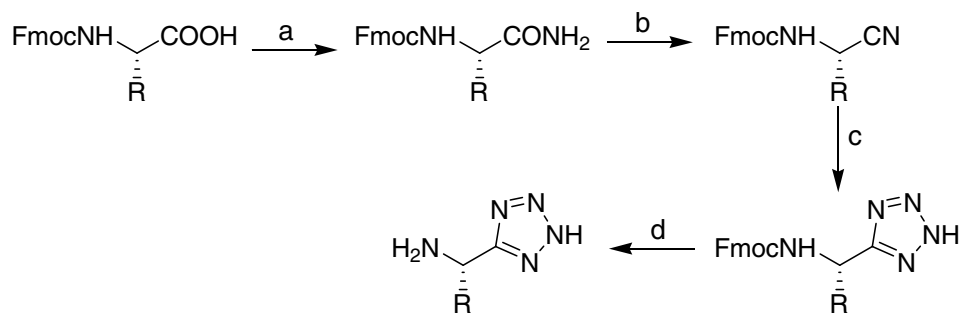

Scheme 1. Reagents and conditions: (a) (Boc) $)_{2} \mathrm{O}$, pyridine, $\mathrm{NH}_{4} \mathrm{HCO}_{3}, \mathrm{rt}, 5 \mathrm{~h}, 70-80 \%$; (b) trifluoroacetic anhydride-pyridine $(1: 1)$, THF, $0{ }^{\circ} \mathrm{C}, 3 \mathrm{~h}$, $85-95 \%$; (c) $\mathrm{NaN}_{3}, \mathrm{ZnBr}_{2}$, water/2-propanol (2:1), $80{ }^{\circ} \mathrm{C}, 16 \mathrm{~h}, 80-90 \%$; (d) diethylamine, $\mathrm{CH}_{2} \mathrm{Cl}_{2}, 30 \mathrm{~min}, 80-94 \%$.

Table 1. $N^{\alpha}$-protected tetrazole analogues of amino acids and amine free tetrazoles

\begin{tabular}{|c|c|c|c|c|c|c|c|c|}
\hline Entry & Fmoc-amino tetrazole ${ }^{a}$ & Yield $(\%)$ & $\mathrm{Mp}\left({ }^{\circ} \mathrm{C}\right)$ & $\operatorname{Mass}^{\mathrm{b}}$ (obs/calc) & $\begin{array}{l}\text { Free amino } \\
\text { tetrazole }^{\mathrm{a}}\end{array}$ & Yield (\%) & $\mathrm{Mp}\left({ }^{\circ} \mathrm{C}\right)$ & $\operatorname{Mass}^{\mathrm{b}}$ (obs/calc) \\
\hline 1 & Fmoc-GlyT & 89 & 181 & $321.3312(321.3333)$ & GlyT & 93 & 274 & $99.0932(99.0946)$ \\
\hline 2 & Fmoc-AlaT & 91 & 189 & $335.3579(335.3598)$ & AlaT & 90 & 257 & $113.1237(113.1211)$ \\
\hline 3 & Fmoc-ValT & 85 & 207 & $363.4147(363.4130)$ & ValT & 88 & 273 & $141.1720(141.1743)$ \\
\hline 4 & Fmoc-LeuT & 86 & 202 & $377.4379(377.4396)$ & LeuT & 89 & 262 & $155.2023(155.2009)$ \\
\hline 5 & Fmoc-IleT & 88 & 219 & $377.4380(377.4396)$ & IleT & 90 & 269 & $155.2001(155.2009)$ \\
\hline 6 & Fmoc-PheT & 90 & 204 & $411.4526(411.4558)$ & PheT & 94 & 278 & $189.2143(189.2171)$ \\
\hline 7 & Fmoc-Ser $(\mathrm{OBz}) \mathrm{T}$ & 82 & 223 & $441.4832(441.4818)$ & $\operatorname{Ser}(\mathrm{OBz}) \mathrm{T}$ & 85 & 243 & $219.2405(219.2431)$ \\
\hline 8 & Fmoc-D-PhgT & 84 & 211 & $397.4275(397.4292)$ & D-PhgT & 87 & 181 & $175.1933(175.1905)$ \\
\hline 9 & Fmoc-L-PhgT & 82 & 186 & $397.4282(397.4292)$ & L-PhgT & 85 & 202 & $175.1919(175.1905)$ \\
\hline 10 & Fmoc-MetT & 89 & 193 & $395.4764(395.4780)$ & MetT & 87 & 233 & $173.2364(173.2393)$ \\
\hline 11 & Fmoc-ProT & 81 & 180 & $361.3949(361.3971)$ & ProT & 83 & 249 & $139.1559(139.1584)$ \\
\hline 12 & Fmoc-Asp $(\mathrm{OBz}) \mathrm{T}$ & 79 & 227 & $469.4902(469.4919)$ & $\mathrm{Asp}(\mathrm{OBz}) \mathrm{T}$ & 81 & 227 & $247.2511(247.2532)$ \\
\hline 13 & Fmoc-Glu $(\mathrm{OBz}) \mathrm{T}$ & 81 & 232 & $483.5164(483.5185)$ & $\mathrm{Glu}(\mathrm{OBz}) \mathrm{T}$ & 84 & 178 & $261.2768(261.2798)$ \\
\hline
\end{tabular}

${ }^{\mathrm{a}} \mathrm{T}$ corresponds to Tetrazole.

${ }^{\mathrm{b}}$ High resolution mass spectrometry (HRMS). 


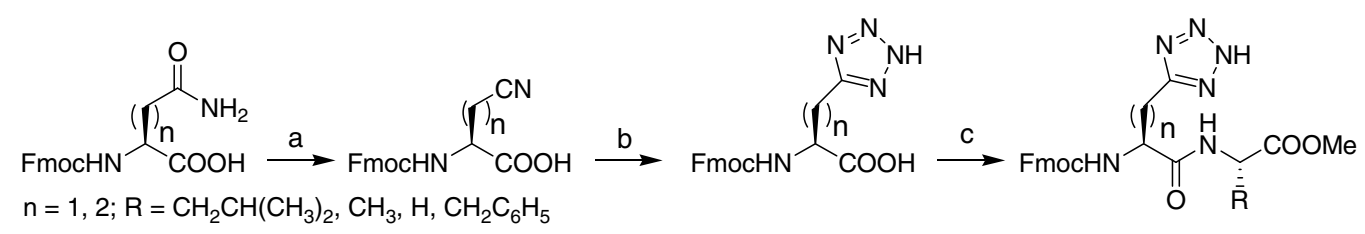

Scheme 2. Reagents and conditions: (a) Trifluoroacetic anhydride-pyridine (1:1), THF, $0{ }^{\circ} \mathrm{C}, 6$ h, 70-80\%; (b) $\mathrm{NaN}_{3}$, $\mathrm{ZnBr}_{2}$, water/2-propanol (2:1), $80{ }^{\circ} \mathrm{C}, 16 \mathrm{~h}, 65-75 \%$; (c) HBTU, DIEA, MeOH, DCM, $0{ }^{\circ} \mathrm{C} \rightarrow \mathrm{rt}, 5 \mathrm{~h}, 80-90 \%$.

Table 2. Synthesis of side chain derived tetrazole analogues of aspartic and glutamic acids and peptides

\begin{tabular}{lllll}
\hline Entry & Compound & Yield $(\%)$ & Mp $\left({ }^{\circ} \mathrm{C}\right)$ & Mass $^{\mathrm{a}}(\mathrm{obs} / \mathrm{calc})$ \\
\hline 1 & Fmoc-Asp(T)-OH & 76 & 202 & $379.3719(379.3734)$ \\
2 & Fmoc-Glu(T)-OH & 79 & 190 & $393.3991(393.4008)$ \\
3 & Fmoc-Asp(T)-Leu-OCH & 163 & $506.5563(506.5581)$ \\
4 & Fmoc-Asp(T)-Ala-OCH & 66 & $464.4765(464.4789)$ \\
5 & Fmoc-Asp(T)-Gly-OCH & 713 & $450.4301(450.4513)$ \\
6 & Fmoc-Asp(T)-Phe-OCH & 71 & 178 & $540.5726(540.5758)$ \\
7 & Fmoc-Glu(T)-Leu-OCH & 74 & 185 & $520.5812(520.5855)$ \\
8 & Fmoc-Glu(T)-Ala-OCH & 69 & 757 & $478.5023(478.5058)$ \\
9 & Fmoc-Glu(T)-Gly-OCH & 71 & 73 & 192 \\
\hline
\end{tabular}

${ }^{\text {a }}$ High resolution mass spectrometry (HRMS).

the side chains. Although, initially we had started our synthesis using Fmoc-Asn-OMe and Fmoc-Gln-OMe, it was found that the entire protocol could be carried out starting from Fmoc-Asn/Gln.

A two-step protocol including conversion of a carboxamido group to a nitrile followed by cycloaddition resulted in Fmoc-Asp(T)-OH and Fmoc-Glu(T)-OH in $76 \%$ and $79 \%$ yields, respectively, which were fully characterized by ${ }^{1} \mathrm{H}$ NMR, ${ }^{13} \mathrm{C}$ NMR and mass spectral studies (Table 2). The tetrazolyl acids were employed as building blocks to prepare peptides possessing a tetrazole unit in the side chain. Fmoc-Asp(T)-OH or FmocGlu(T)-OH was coupled with amino acid methyl ester hydrochlorides using the standard HBTU and DIEA methods. The coupling was carried out at $0{ }^{\circ} \mathrm{C}$ in DCM and the reaction mixture was allowed to warm to room temperature over $5 \mathrm{~h}$. After work-up, the products were isolated as solids in yields around $80-90 \%$.

In conclusion, tetrazole analogues of amino acids/peptides have been synthesized through an Fmoc-amino protection strategy. The use of Fmoc for amine protection facilitated the easy isolation of intermediate nitriles and final tetrazoles. Amino free tetrazoles were obtained by deprotection of the Fmoc group under mild reaction conditions. The tetrazole-containing unnatural amino acids isosteric to Asp/Glu have been similarly synthesized from Fmoc-Asn/Gln and utilized in the synthesis of peptides. In all cases, the final tetrazole products were isolated in high yields and purities.

\section{Acknowledgements}

We are grateful to the Department of Science and Technology (DST), Government of India, for financial assistance. R.V.R. acknowledges the CSIR, New Delhi, for a SRF.

\section{References and notes}

1. (a) Bavetsias, V.; Marriott, J. H.; Melin, C.; Kimbell, R.; Matusiak, Z. S.; Thomas Boyle, F.; Jackman, A. L. J. Med. Chem. 2000, 43, 1910-1926; (b) Upadhayaya, R. S.; Jain, S.; Sinha, N.; Kishore, N.; Chandra, R.; Arora, S. K. Eur. J. Med. Chem. 2004, 39, 579-592.

2. (a) Beusen, D. D.; Zabrocki, J.; Slomczynska, U.; Head, R. D.; Kao, J. L. F.; Marshall, G. R. Biopolymers 1995, 36, 181-200; (b) Zabrocki, J.; Smith, G. D.; Dunbar, J. B., Jr.; Iijima, H.; Marshall, G. R. J. Am. Chem. Soc. 1988, 110, 5875-5880; (c) Zabrocki, J.; Dunbar, J. B.; Marshall, K. W.; Toth, M. V.; Marshall, G. R. J. Org. Chem. 1992, $57,202-209$.

3. (a) Thornber, C. W. Chem. Soc. Rev. 1979, 8, 563-580; (b) Wittenberger, S. J. Org. Prep. Proced. Int. 1994, 26, 499531.

4. (a) Knudsen, K. R.; Mitchell, C. E. T.; Ley, S. V. Chem. Commun. 2006, 66-68; (b) Torii, H.; Nakadai, M.; Ishihara, K.; Saito, S.; Yamamoto, H. Angew. Chem., Int. Ed. 2004, 43, 1983-1986; (c) Chowdari, N. S.; Ahmad, M.; Albertshofer, K.; Tanaka, F.; Barbas, C. F., III. Org. Lett. 2006, 8, 2839-2842.

5. (a) Lodyga-Chruscinska, E.; Sanna, D.; Micera, G.; Chruscinki, L.; Olejnik, J.; Nachman, R. J.; Zabrocki, J. Acta. Biochim. Pol 2006, 53, 65-72; (b) Lodyga-Chruscinska, E.; Oldziej, S.; Micera, G.; Sanna, D.; Chruscinki, L.; Olczak, J.; Zabrocki, J. J. Inorg. Biochem. 2004, 98, 447-458; (c) Lee, K.; Kim, Y.; Baeck, K. K. J. Organomet. Chem. 2005, 690, 4319-4329.

6. (a) Kabada, P. K. Synthesis 1973, 71-84; (b) Herbst, R. M.; Froberger, C. F. J. Org. Chem. 1957, 22, 1050-1053; (c) Finnegan, W. G.; Henry, R. A.; Lofquist, R. J. Am. Chem. Soc. 1958, 80, 3908-3911.

7. (a) Demko, Z. P.; Sharpless, K. B. J. Org. Chem. 2001, 66, 7945-7950; (b) Demko, Z. P.; Sharpless, K. B. Org. Lett. 2002, 4, 2525-2527.

8. (a) Grzonka, Z.; Liberek, B. Roczniki. Chem. 1971, 45, 967-980; (b) Grzonka, Z.; Rekowska, E.; Liberek, B. Tetrahedron 1971, 27, 2317-2322.

9. Cobb, A. J. A.; Shaw, D. M.; Longbottom, D. A.; Gold, J. B.; Ley, S. V. Org. Biomol. Chem. 2005, 3, 84-96. 
10. Saaby, S.; Knudsen, K. R.; Ladlow, M.; Ley, S. V. Chem. Commun. 2005, 2909-2911.

11. Atherton, E.; Sheppard, R. C. In Solid-Phase Peptide Synthesis; Rickwood, D., Hames, B. D., Eds.; IRL Press: Oxford, 1989.

12. Pozdnev, V. F. Tetrahedron Lett. 1995, 36, 7115-7118.

13. Campagna, F.; Carotti, A.; Casini, G. Tetrahedron Lett. 1977, 21, 1813-1816.

14. General procedure for the synthesis of tetrazole analogues of $N^{\alpha}$-Fmoc-amino acids: $N^{\alpha}$-Fmoc-amino nitrile $(1 \mathrm{mmol})$, sodium azide $(2 \mathrm{mmol})$ and zinc bromide $(0.5 \mathrm{mmol})$ were dissolved in a mixture of 2-propanol $(15 \mathrm{~mL})$ and water $(30 \mathrm{~mL})$, and stirred at reflux for $16 \mathrm{~h}$. After completion of the reaction [as monitored by TLC, using chloroform:methanol (9:1) as eluant], $5 \mathrm{~mL}$ of $3 \mathrm{~N} \mathrm{HCl}$ and $30 \mathrm{~mL}$ of ethyl acetate were added and stirring was continued until no solid remained. The aqueous layer was extracted twice with ethyl acetate. The combined organic layer was washed with water and dried over anhydrous $\mathrm{Na}_{2} \mathrm{SO}_{4}$. The solvent was removed in vacuo and the residue was recrystallized from EtOAc/hexane (1:4). Compound characterization data for Fmoc-ValT (Table 1, entry 3): IR (KBr) 1692, 1533, $1263 \mathrm{~cm}^{-1}$; ${ }^{1} \mathrm{H}$ NMR $\left(\mathrm{CDCl}_{3}, 400 \mathrm{MHz}\right): \delta 0.91(\mathrm{t}, J=6.8 \mathrm{~Hz}, 6 \mathrm{H}), 1.06(\mathrm{~m}$, $1 \mathrm{H}), 4.20(\mathrm{t}, J=6.6 \mathrm{~Hz}, 1 \mathrm{H}), 4.54(\mathrm{~d}, J=6.6 \mathrm{~Hz}, 2 \mathrm{H})$, 5.07 (br d, $J=5.8 \mathrm{~Hz}, 2 \mathrm{H}), 7.24-7.78(\mathrm{~m}, 8 \mathrm{H}) ;{ }^{13} \mathrm{C} \mathrm{NMR}$ $\left(\mathrm{CDCl}_{3}, 100 \mathrm{MHz}\right): \delta 19.1,26.3,37.2,39.1,45.7,48.5$, 66.2, 120.4, 124.6, 126.4, 127.1, 140.9, 148.6, 154.5.

Fmoc-LeuT (Table 1, entry 4): IR (KBr) 1693, 1538, $1264 \mathrm{~cm}^{-1} ;{ }^{1} \mathrm{H} \mathrm{NMR}\left(\mathrm{CDCl}_{3}, 400 \mathrm{MHz}\right): \delta 0.94-0.96(\mathrm{t}$,
$J=6.8 \mathrm{~Hz}, 6 \mathrm{H}), 1.67(\mathrm{~m}, 1 \mathrm{H}), 1.97(\mathrm{t}, J=8.4 \mathrm{~Hz}, 2 \mathrm{H})$, $4.18(\mathrm{t}, J=5.9 \mathrm{~Hz}, 1 \mathrm{H}), 4.52(\mathrm{~d}, J=5.9 \mathrm{~Hz}, 1 \mathrm{H}), 5.13(\mathrm{~d}$, $J=6 \mathrm{~Hz}, 2 \mathrm{H}), 5.40(\mathrm{br} \mathrm{d}, J=5.9 \mathrm{~Hz}, 1 \mathrm{H}), 7.22-7.79(\mathrm{~m}$, $8 \mathrm{H}) ;{ }^{13} \mathrm{C} \mathrm{NMR}\left(\mathrm{CDCl}_{3}, 100 \mathrm{MHz}\right): \delta 21.9,24.1,36.5$, $39.5,40.6,46.6,65.6,120.0,125.1,126.9,127.5,140.7$, 143.6, 143.8, 155.8.

15. General procedure for deprotection of the Fmoc group: To a solution of $N^{\alpha}$-Fmoc-protected amino tetrazole $(1 \mathrm{mmol})$ in dry $\mathrm{CH}_{2} \mathrm{Cl}_{2}$ was added diethylamine $(2 \mathrm{~mL})$ and the mixture was stirred at room temperature for $30 \mathrm{~min}$. After completion of the reaction (as monitored by TLC), the solvent was removed in vacuo. The crude product was recrystallized from EtOAc/hexane (1:4) to obtain the free $\alpha$-amino tetrazole as a solid.

Compound characterization data for: Alanine tetrazole (Table 1, entry 2): IR (KBr) $1535,1442,1266 \mathrm{~cm}^{-1} ;{ }^{1} \mathrm{H}$ NMR $\left(\mathrm{CDCl}_{3}, 400 \mathrm{MHz}\right): \delta 1.49(\mathrm{~d}, J=6.1 \mathrm{~Hz}, 3 \mathrm{H}), 4.15$ $(\mathrm{m}, 1 \mathrm{H}), 4.93(\mathrm{br} \mathrm{d}, J=6.6 \mathrm{~Hz}, 2 \mathrm{H}) ;{ }^{13} \mathrm{C} \mathrm{NMR}\left(\mathrm{CDCl}_{3}\right.$, $100 \mathrm{MHz}): \delta 21.5,46.6,151.3$.

Leucine tetrazole (Table 1, entry 4): IR (KBr) 1532, 1444, $1263 \mathrm{~cm}^{-1} ;{ }^{1} \mathrm{H}$ NMR $\left(\mathrm{CDCl}_{3}, 400 \mathrm{MHz}\right): \delta 0.86-0.88(\mathrm{~d}$, $J=4.8 \mathrm{~Hz}, 6 \mathrm{H}), 1.65(\mathrm{~m}, 1 \mathrm{H}), 1.97(\mathrm{t}, J=5.8 \mathrm{~Hz}, 2 \mathrm{H})$, $2.81(\mathrm{br} \mathrm{d}, J=6.6 \mathrm{~Hz}, 2 \mathrm{H}), 3.72(\mathrm{q}, J=6.2 \mathrm{~Hz}, 1 \mathrm{H}) ;{ }^{13} \mathrm{C}$ $\mathrm{NMR}\left(\mathrm{CDCl}_{3}, 100 \mathrm{MHz}\right): \delta 23.8,24.2,42.5,46.1,150.3$.

16. Racemization studies: The enantiomeric purities of the synthesized tetrazoles were preserved appreciably following the present method. The reaction sequence yields tetrazoles with ee's exceeding $80 \%$ as determined by chiral HPLC studies of the corresponding methylated derivatives. 